\title{
Determinants of Patient Satisfaction with Hospital Service Quality in the Context of Iranian Health Care Market
}

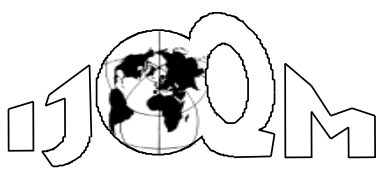

DOI: $10.46970 / 2021.27 .3 .6$

Volume 27, Number 3

September 2021, pp. 287-302

\author{
Rassoul Noorossana \\ Adel Talaei Delshad \\ Iran University of Science and Technology \\ (rassoul@iust.ac.ir) \\ (adel.talaei@yahoo.com)
}

Mohamad R. Nayebpour

Marilyn Davies College of Business

University of Houston-Downtown

(nayebpourm@uhd.edu)

This research aims to investigate the structural relationships between inpatient satisfaction and service quality dimensions. To that end, a multidimensional model was developed and empirically validated. Exploratory factor analysis, confirmatory factor analysis, and structural equation modelling were applied to specify the relationships between service quality dimensions and satisfaction. Results indicated that the general causal relationship between service quality and inpatient satisfaction was well supported in the Iranian health care delivery system. The research identified twenty-two items driving four primary dimensions which were positively related to patient satisfaction. The primary dimensions were interpersonal relationship, administrative processes, amenities, and physician care.

Keywords: Patient Satisfaction, Service Quality, Health Service, SEM analysis

\section{Introduction}

Patient satisfaction plays a key role in health care delivery system. Research indicate that patient satisfaction is associated with appointment keeping, behavioral intentions to comply with recommended treatment and medication use (Williams, 1994). In addition to its positive impact on patients' behavioral intentions and loyalty (Dagger et al., 2007; Mohamed and Azizan, 2015; Shabbir et al., 2016) health service performance can be improved by monitoring patient satisfaction (Andaleeb, 2001; Naidu, 2009). Several recent studies have shown that patient satisfaction is significantly influenced by perceived service quality (Lee et al., 2000; Choi et al., 2005; Dagger et al., 2007; Mohamed and Azizan, 2015; Johnson and Russell, 2015; Swain and Kar, 2018).

Therefore, in order to understand factors affecting patient satisfaction, researchers have probed various service quality dimensions that shape the patient's perception of service quality (Dagger et al., 2007; Naidu, 2009). Furthermore, to implement patientoriented quality assessment measures, it would be essential for health care providers to understand what dimensions of service quality most satisfy patients (Clemes, et al., 2001; Zineldin, 2006). However, when customer is the patient, the constructs and 
theory underlying satisfaction are not particularly simple (Berry and Bendapudi, 2007; Hekman et al., 2010), and validity of patient satisfaction measures have been called into question (Gill and White, 2009).

It is commonly accepted that the patient socio-cultural, health status, and geographic location are associated with satisfaction (Tucker, 2002; Batbaatar et al., 2017). Thus, it comes as no surprise that the dimensions of healthcare service quality may vary based on patient priorities in different nations and healthcare delivery contexts. During recent years, in many developing countries there has been heightened interest in investigating dimensions of service quality that significantly influence satisfaction from patients' viewpoint (Kim et al., 2017; Mohamed and Azizan, 2015; Shabbir et al., 2016; Zineldin et al., 2011; Aagja and garg, 2010). Yet, a few studies have conducted addressing this issue in the context of Iranian health care market. (Zarei at el., 2014; Zarei, 2015; Ziapour et al., 2016; Ravangard et al., 2017).

In this study we investigated that what dimensions of healthcare service quality are significantly related to satisfaction based on Iranian inpatient preferences. The model was validated by using confirmatory factor analysis (CFA) and the hypothesis were tested by taking advantage of structural equation modeling methods (SEM). This study highlights the importance of service quality-satisfaction relationship in the healthcare sector and provides implications to managers and practitioners working in the field.

\section{Literature Review and Theoretical Framework}

\subsection{Service Quality Perception}

Perceived service quality has been generally defined as a consumer's judgment regarding the overall excellence or superiority of the service (Parasuraman et al., 1988; Zeithaml, 1988). This judgment is often depicted as a consumer's comparison between expectations of service and actual service perceptions (Gronroos, 1984; Parasuraman et al., 1985). Gronroos (1984) based on consumers' comparison of perceived and expected service in evaluating service quality, developed a model in which he suggests that perceived service quality might be divided into two sets: functional quality (how the service is provided) and technical quality (what is provided).

Parasuraman et al. (1985) proposed SERVQUAL model and its five dimensions based on the gap between expected and perceived service. Although this approach has been widely applied and accredited, but it has attracted considerable criticism. Several researchers suggested that when the objective is to measure service quality perceptions, the measurement of service perceptions (performance-based measures) conducted better than measuring discrepancy between expectations and perceptions (Dabholkar, et al., 2000; Babakus and Boller, 1992; Cronin and Taylor, 1992; Brady and Cronin, 2001). In addition, cultural values affect service quality perceptions and expectations and consumers in different cultures have dissimilar interpretations of SERVQUAL dimensions (Karami et al., 2016). Furthermore, using SERVQUAL scale in the context of health care services has yielded mix results (Clemes et al., 2001; Dagger et al., 2007). For example, Wisniewski and Wisniewski (2005) supported 5factor SERVQUAL as a useful instrument for assessing service quality in a hospital colposcopy clinic, Butt and de Run (2010) using SERVQUAL instrument indicated that the original 5-factor structure is valid for measuring service quality in the private healthcare sector. Herstein and Gamliel (2006) suggested private branding as an 
additional sixth dimension of the SERVQUAL model, Ramsaran-Fowdar (2008) identified 7 factors in a study on private hospitals when using the original SERVQUAL scale, and Karassavidou et al. (2009) revealed a three-dimension SERVQUAL construct for measuring quality in Greek hospitals. Also, Meesala and Paul (2018) found that only two dimensions of the SERVQUAL (reliability and responsiveness) significantly impact patients' satisfaction in a populous developing country. Thus, many researchers have tested other instruments or developed their own scale to conceptualize and measure perceived service quality in the healthcare setting.

\subsection{Patient Satisfaction and Service Quality Perception}

In the context of service delivery, satisfaction has been conceptualized as a consumers' positive affective response resulting from an evaluation about the quality of the services provided. (Oliver, 1980; Spreng and MacKoy, 1996; Westbrook and Oliver, 1991). This concept implies that satisfaction is an emotional reaction to a service experience which occurs as a consequence of an evaluation process. This evaluation process of service quality is an essential aspect of customer satisfaction (Ryu et al., 2008). Several researchers have suggested and empirically supported that perceived service quality is an antecedent of customer satisfaction. This casual order is obtained through the findings of Woodside et al. (1989), Cronin and Taylor (1992), Oliver (1993), Spreng and MacKoy (1996), Lee et al. (2000) and Brady and Robertson, (2001). Swain and Kar (2018) proposed that hospital service quality is an antecedent of patient satisfaction based on extensive review of existing literature on hospital service quality, patient satisfaction and behavioral intention.

Therefore, we expected that patient satisfaction as a construct could be operationalized by determining perceived service quality dimensions. In recent years, important efforts have been done to understand how medical service quality is perceived by patients. Human disease is inherently complex and there is not a best course of treatment. The risks and benefits of each treatment option for an individual patient are unknown (Nembhard, Alexander, Hoff, \& Ramanujam, 2009). Thus, hospital patients are likely to be keen for any "clues" and evidence of the hospital's competence and caring while evaluating the service quality during and after use (Berry et al., 2006). Donabedian (1992), believed that health care quality consisted of three primary elements: technical task, interpersonal exchange and the amenities of care. According to this view the quality of technical care is defined not by what is done, but by what is accomplished in line with patient preferences, and the quality of interpersonal care is defined as the interaction between the service provider and consumer based on consumer's needs and expectation. Also, the amenities of care as the third element of health care quality is described as the circumstances under which the task is performed and the exchange occurs. As previously mentioned, past studies have developed their own scale to determine health care service quality dimensions which have significant influence on patient satisfaction. For example, Reidenbach and Sandifer-Smallwood (1990) conducted a factor analysis and extracted patient confidence, business competence, treatment quality, support services, physical appearance, waiting time and empathy as service quality dimensions which positively and strongly correlated with patient satisfaction. It is proved that various dimensions have different priorities depending on patients' preferences in different countries, culture and medical settings. We studied articles that investigated health care service quality factors which impact on satisfaction. A summaries of service quality 
dimensions influencing patient satisfaction from selected previous studies in different countries are presented in table 1.

Table 1 Summaries of hospital service quality dimensions

\begin{tabular}{|c|c|c|}
\hline Study & Country settings & Service quality dimensions \\
\hline Andaleeb (2001) & Bangladesh & $\begin{array}{l}\text { responsiveness, assurance, communication, } \\
\text { discipline, and baksheesh }\end{array}$ \\
\hline Choi et al. (2005) & South Korea & $\begin{array}{l}\text { physician concern, staff concern, Convenience } \\
\text { of the care process, and tangibles. }\end{array}$ \\
\hline Zineldin (2006) & Egypt and Jordan & $\begin{array}{l}\text { quality of object (technical quality), quality of } \\
\text { processes (functional quality), quality of } \\
\text { infrastructure, quality of interaction, and quality } \\
\text { of atmosphere. }\end{array}$ \\
\hline Dagger et al. (2007) & Australia & $\begin{array}{l}\text { interpersonal quality, technical quality, } \\
\text { environment quality, and administrative quality. }\end{array}$ \\
\hline Elleuch (2008) & Japan & $\begin{array}{l}\text { process characteristics (patient-provider } \\
\text { interaction) and physical attributes (settings and } \\
\text { appearance). }\end{array}$ \\
\hline $\begin{array}{l}\text { Badri and Attia } \\
\quad(2008)\end{array}$ & UAE & $\begin{array}{l}\text { quality of care, process and administration, and } \\
\text { information. }\end{array}$ \\
\hline $\begin{array}{l}\text { Duggirala et al. } \\
\text { (2008) }\end{array}$ & India & $\begin{array}{l}\text { infrastructure, personnel quality, process of } \\
\text { clinical care, administrative procedures, safety } \\
\text { indicators, overall experience of medical care } \\
\text { received, and social responsibility. }\end{array}$ \\
\hline $\begin{array}{l}\text { Aagja and Garg } \\
\qquad(2010)\end{array}$ & India & $\begin{array}{l}\text { admission, medical service, overall service, } \\
\text { discharge process, and social responsibility. }\end{array}$ \\
\hline $\begin{array}{c}\text { Amin and } \\
\text { Nasharuddin (2013) }\end{array}$ & Malaysia & $\begin{array}{l}\text { admission, medical service, overall Service, } \\
\text { discharge, and social responsibility. }\end{array}$ \\
\hline Zarei et al. (2014) & Iran & $\begin{array}{l}\text { perceived value, quality of process, and quality } \\
\text { of interaction. }\end{array}$ \\
\hline $\begin{array}{l}\text { Mohamed and } \\
\text { Azizan (2015) }\end{array}$ & Malaysia & $\begin{array}{l}\text { infrastructure, interaction, administrative } \\
\text { procedure, medical care, and nursing care. }\end{array}$ \\
\hline Shabbir et al. (2016) & Pakistan & $\begin{array}{l}\text { physician care, operational activities, and } \\
\text { physical maintenance. }\end{array}$ \\
\hline Kim et al. (2017) & South Korea & $\begin{array}{c}\text { treatment effectiveness (physician performance } \\
\text { and quality of service procedures), and facilities } \\
\text { and environment. }\end{array}$ \\
\hline
\end{tabular}


A comparison of the health care service quality dimensions identified by researchers indicates that although they include some similarities but the number and nature of dimensions and sub-dimensions might vary across country settings and cultural differences.

\subsection{Iranian Health Care Delivery System}

Healthcare delivery system in Iran is categorized into the public-governmental sector, the private sector, and nongovernmental organizations (NGOs). The publicgovernmental sector is the main provider of primary health care services and provides a considerable part of secondary and tertiary health services across the country. The private sector mainly focuses on secondary and tertiary health care in urban areas. In addition, there are many nongovernmental organizations (NGOs) mainly active in special fields like children with cancer, breast cancer, diabetes, thalassemia, and so on. The Ministry of Health and Medical Education delegates its implementation to medical universities across the country. There is at least one medical university in every province which is responsible for planning, monitoring, training and supervision of teaching hospitals. As an important point, Article 29 of the Constitution of the Islamic Republic of Iran emphasizes that every Iranian has the right to enjoy the highest attainable level of health (Mehrdad, 2009).

\subsection{Sample and Setting}

\section{Methodology}

The study was conducted at a teaching hospital with 121 beds located in Hamadan, Iran. The survey was conducted on a sample of 260 recently discharged patients who received inpatient medical services at the hospital. In this study, we used a convenience sample which is a commonly used method in marketing research (Senic' and Marinkovic', 2013). The patients were assured that their answers would be retained confidential. From this random sampling, 13 questionnaires were returned incomplete and a total of 247 questionnaires were used for the final data analysis. A summary of the respondent's demographic characteristics is provided in Table 2.

Table 2 Demographic characteristics

\begin{tabular}{|cl|c|c|}
\hline \multicolumn{2}{|c|}{ Demographic variable } & Frequency (n) & Percentage (\%) \\
\hline \multirow{2}{*}{ Gender } & Female & 101 & $40.9 \%$ \\
\cline { 2 - 4 } & Male & 146 & $59.1 \%$ \\
\hline \multirow{3}{*}{ Age } & $\leq 29$ & 4 & $1.6 \%$ \\
\cline { 2 - 4 } & $30-49$ & 36 & $14.6 \%$ \\
\cline { 2 - 4 } & $50-69$ & 133 & $53.8 \%$ \\
\cline { 2 - 4 } Education & $70-89$ & 74 & $30 \%$ \\
\cline { 2 - 4 } & high school & 178 & $72.1 \%$ \\
\cline { 2 - 4 } & undergraduate degree & 60 & $24.3 \%$ \\
\cline { 2 - 4 } & postgraduate degree & 9 & $3.6 \%$ \\
\hline
\end{tabular}

The final sample consisted of 146 males and 101 females. Respondents' average age was 58.7 years $(\mathrm{SD}=15.2)$. Most of them had a high school degree (72.1 percent), 
some had an undergraduate degree (24.3 percent), and others had a postgraduate degree (3.6 percent).

\subsection{Scale Development}

In order to develop a scale to measure the perceived service quality by Iranian healthcare consumers, we began by exploring frequently cited dimensions and subdimensions of service quality in the marketing literature, as summarized in the previous section. Because of the differences in country setting and culture, measurement items of service quality translated and developed precisely. Then, by investigating VOC hospital's documentations, we compared dimensions and subdimensions identified from the literature with patients' needs, requirements and preferences so as to understand how Iranian inpatient viewed health care services. Through this process, 22 items were developed based on the results of the VOC documentation and by modifying the service quality items obtained from the literature. All 22 items used a five-point Likert scale (scores 1-5).

The second construct, patient satisfaction, was operationalized using two global items. The global satisfaction items were "how satisfied were you with the treatment you received in the hospital?" and "how satisfied were you with your decision to use the hospital?" and a five-point Likert-type scale was used to capture the patients' overall feelings of satisfaction toward the hospital ranging from 1 (VERY UNSATISFIED) to 5 (VERY SATISFIED) (Cronin and Taylor, 1992; Bendall-Lyon and Powers, 2004; Elleuch, 2008).

\subsection{Data Analysis}

The analysis of the survey data was performed in three steps. The first step was to determine the hospital's service quality dimensions and the items applicable to every dimension by carrying out exploratory factor analysis (principal component analysis and varimax rotation methods). To evaluate the suitability of the data for factor analysis the Kaiser-Meyer-Olkin (KMO) test and the Bartlett's Test of Sphericity (BTS) were used. The criterion for the number of factors extracted was determined by eigenvalues. The factors having eigenvalues of 1 or more were extracted for further inspection. The items of each factor were considered practically significant only if they had a factor loading of higher than \pm 0.5 and cross-loading of less than 0.4 relevant to the other factors (Hair et al., 2019).

In the second step, the validity of the measurement model was tested using confirmatory factor analysis (CFA). As one of the primary objectives of CFA, construct validity was performed through convergent and discriminant validities so as to determine to what extent variables measure theoretical latent constructs. The relative amount of convergent validity among item measures was estimated through factor loadings, average variance extracted (AVE), and construct reliability (CR). Discriminant validity was confirmed by the fact that the AVE of each dimension should be greater than the squared correlation between that dimension and the other dimensions. Also, the presence of cross-loadings indicates a discriminant validity problem. In the third step, after completing the CFA, causal structure validity of hypothesized relationships between latent variables (constructs) was tested using structural equation modeling (SEM). All of the statistical analyses were conducted using IBM SPSS 19 and LISREL 8.80 applications. 


\section{Results}

\subsection{Exploratory Factor Analysis (EFA)}

The results from BTS were statistically significant (p-value $<0.001$ ), and KMO measure of sampling adequacy value (0.892) showed that the data was well suited for factor analysis. EFA revealed four main dimensions for service quality, which explained 72.6 percent of the total variance. Considering the sample size of 247, the factor loadings of \pm 0.5 or greater are deemed both practically and statistically significant (Hair et al., 2019). All factor loadings were higher than 0.5, which was greater than the recommended level. The results of EFA are presented in Table 3.

Table 3 Exploratory Factor Analysis Results

\begin{tabular}{|c|c|c|c|c|c|}
\hline Dimensions / items & Mean & Loading & Eigenvalue & $\begin{array}{c}\text { Explained } \\
\text { variance }\end{array}$ & $\begin{array}{c}\text { Cronbach's } \\
\alpha \\
\end{array}$ \\
\hline 1. Interpersonal relationship & & & 7.6 & 34.7 & 0.963 \\
\hline $\begin{array}{l}\text { Q11: physicians treat with respect } \\
\text { and dignity }\end{array}$ & 4.05 & 0.863 & & & \\
\hline $\begin{array}{l}\text { Q12: physicians treat patient } \\
\text { politely }\end{array}$ & 3.92 & 0.888 & & & \\
\hline $\begin{array}{l}\text { Q13: nurses' empathy and } \\
\text { individual attention }\end{array}$ & 3.93 & 0.915 & & & \\
\hline Q14: friendly and courteous nurses & 3.92 & 0.940 & & & \\
\hline Q15: nurses respond immediately & 3.87 & 0.874 & & & \\
\hline Q16: helpful staff & 3.89 & 0.894 & & & \\
\hline 2. Administrative processes & & & 3.5 & 16.2 & 0.948 \\
\hline Q17: quick and easy admission & 3.95 & 0.823 & & & \\
\hline Q18: waiting time for surgery & 4.00 & 0.879 & & & \\
\hline Q19: waiting time for medication & 3.97 & 0.880 & & & \\
\hline Q20: waiting time for medical tests & 3.92 & 0.860 & & & \\
\hline $\begin{array}{l}\text { Q21: waiting time for physicians' } \\
\text { appointment }\end{array}$ & 3.95 & 0.864 & & & \\
\hline Q22: quick and easy discharge & 3.97 & 0.908 & & & \\
\hline 3. Amenities & & & 3.1 & 14.4 & 0.845 \\
\hline Q1: neat and clean environment & 3.61 & 0.617 & & & \\
\hline Q2: ambient condition & 3.67 & 0.772 & & & \\
\hline Q3: calm and quiet environment & 3.64 & 0.753 & & & \\
\hline Q4: up-to-date equipment & 3.96 & 0.786 & & & \\
\hline $\begin{array}{l}\text { Q5: tasty meals, adapted to } \\
\text { patients' nutritious needs }\end{array}$ & 3.67 & 0.776 & & & \\
\hline Q6: clean toilets & 3.26 & 0.594 & & & \\
\hline Q7: clarity of signs and directions & 3.93 & 0.702 & & & \\
\hline 4. Physician care & & & 1.5 & 7.2 & 0.859 \\
\hline $\begin{array}{l}\text { Q8: knowledgeable and competent } \\
\text { physicians }\end{array}$ & 4.43 & 0.836 & & & \\
\hline $\begin{array}{l}\text { Q9: complete and careful attention } \\
\text { to the patient's words }\end{array}$ & 4.35 & 0.794 & & & \\
\hline $\begin{array}{l}\text { Q10: good describing of the } \\
\text { recommended treatment plan to the } \\
\text { patient }\end{array}$ & 4.60 & 0.845 & & & \\
\hline
\end{tabular}


The dimensions were labelled based on the contents of their item measures. Dimension 1 included six items, which explained 34.7 percent of the total variance, labelled "Interpersonal relationship"; Dimension 2 included six items, which explained 16.2 percent of the total variance, labelled "Administrative processes"; Dimension 3 included seven items, which explained 14.4 percent of the total variance, labelled "Amenities"; Dimension 4 included three items, which explained 7.2 percent of the total variance, labelled "Physician care". Internal consistency was assessed by Cronbach's alphas and composite reliability scores. All Cronbach's alphas coefficients and composite reliability values are higher than 0.70 .

\subsection{Reliability and Validity}

In the second step, confirmatory factor analysis (CFA) was subsequently conducted for the observed variables (22 items) and the latent variables (service quality dimensions) to confirm validity of pre-specified measurement model. Convergent validity was assessed through three stages (see table 4). First, all factor loadings were higher than 0.5, thereby indicating that they converge on their pre-specified dimensions. Second, the AVE measures ranged from 0.44 to 0.96 . The highest AVE belonged to the "interpersonal relationship" dimension, and the lowest represented the "amenities". All AVE values exceeded 0.50 except for one case that were below 50 percent, showing that almost the majority of the variance is explained by the dimensions. Third, the composite reliabilities were higher than 0.70 , indicating a high level of internal consistency (Hair et al., 2019).

To examine discriminant validity, the squares of the correlations among the dimensions were lower than the corresponding AVE values (see table 4). In addition, there were not any presence of cross-loadings higher than 0.4 among items. These results provide good evidence of discriminant validity. Therefore, the results of CFA suggested that the measurement model for inpatient perception of service quality was satisfactory.

Table 4 Measurement Validation

\begin{tabular}{|c|c|c|c|c|c|c|}
\hline Dimensions & AVE & CR & $\begin{array}{c}\text { Interpersonal } \\
\text { relationship }\end{array}$ & $\begin{array}{c}\text { Administrative } \\
\text { operation }\end{array}$ & Amenities & $\begin{array}{c}\text { Physician } \\
\text { care }\end{array}$ \\
\hline $\begin{array}{c}\text { Interpersonal } \\
\text { relationship }\end{array}$ & 0.8112 & 0.963 & $\mathbf{0 . 8 1}$ & & & \\
\hline $\begin{array}{c}\text { Administrative } \\
\text { processes }\end{array}$ & 0.7578 & 0.9491 & 0.10 & $\mathbf{0 . 7 5}$ & & \\
\hline Amenities & 0.4447 & 0.84 & 0.02 & 0.04 & $\mathbf{0 . 4 4}$ & \\
\hline Physician care & 0.6851 & 0.812 & 0.20 & 0.20 & 0.04 & $\mathbf{0 . 6 8}$ \\
\hline
\end{tabular}

\subsection{Hypothesis Testing}

In the third stage of analysis, SEM was used to examine the relationships between four dimensions of service quality and patient satisfaction. The following hypotheses were developed: 
- Hypothesis1: The quality of interpersonal relationship is positively related to patient satisfaction.

- Hypothesis 2: The quality of administrative processes is positively related to patient satisfaction.

- Hypothesis 3: The quality of amenities is positively related to patient satisfaction.

- Hypothesis 4: The quality of physician care is positively related to patient satisfaction.

H1 postulates a positive relationship between Interpersonal relationship and patient satisfaction, which was supported $(\mathrm{V}=0.52 ; \mathrm{t}=10.98 ; \mathrm{p}=0.000)$. H2 which proposed that administrative process has a positive impact on patient satisfaction, was also supported $(\mathrm{\gamma}=0.46 ; \mathrm{t}=9.99 ; \mathrm{p}=0.000)$. Hospital amenities was positively associated with patient satisfaction, supporting $\mathrm{H} 3(\mathrm{~V}=0.33 ; \mathrm{t}=8.27 ; \mathrm{p}=0.000)$. Finally, physician care was found to positively associated with patient satisfaction, providing support for $\mathrm{H} 4(\mathrm{~V}=0.23 ; \mathrm{t}=5.14 ; \mathrm{p}=0.000)$. Table 5 provides a summary of the hypotheses and results.

Table 5 Summary of Hypotheses and Results

\begin{tabular}{|c|c|c|c|c|c|c|}
\hline \multicolumn{4}{|c|}{ Hypothesis } & Effect & t-value & Supported \\
\hline H1: & Interpersonal relationship & $\rightarrow$ & $\begin{array}{l}\text { Patient } \\
\text { Satisfaction }\end{array}$ & 0.52 & 10.98 & Yes \\
\hline $\mathrm{H} 2$ : & Administrative processes & $\rightarrow$ & $\begin{array}{l}\text { Patient } \\
\text { Satisfaction }\end{array}$ & 0.46 & 9.99 & Yes \\
\hline H3: & Amenities & $\rightarrow$ & $\begin{array}{l}\text { Patient } \\
\text { Satisfaction }\end{array}$ & 0.33 & 8.27 & Yes \\
\hline H4: & Physician care & $\rightarrow$ & $\begin{array}{l}\text { Patient } \\
\text { Satisfaction }\end{array}$ & 0.23 & 5.14 & Yes \\
\hline
\end{tabular}

Figure 1 shows the results of the estimated structural model.

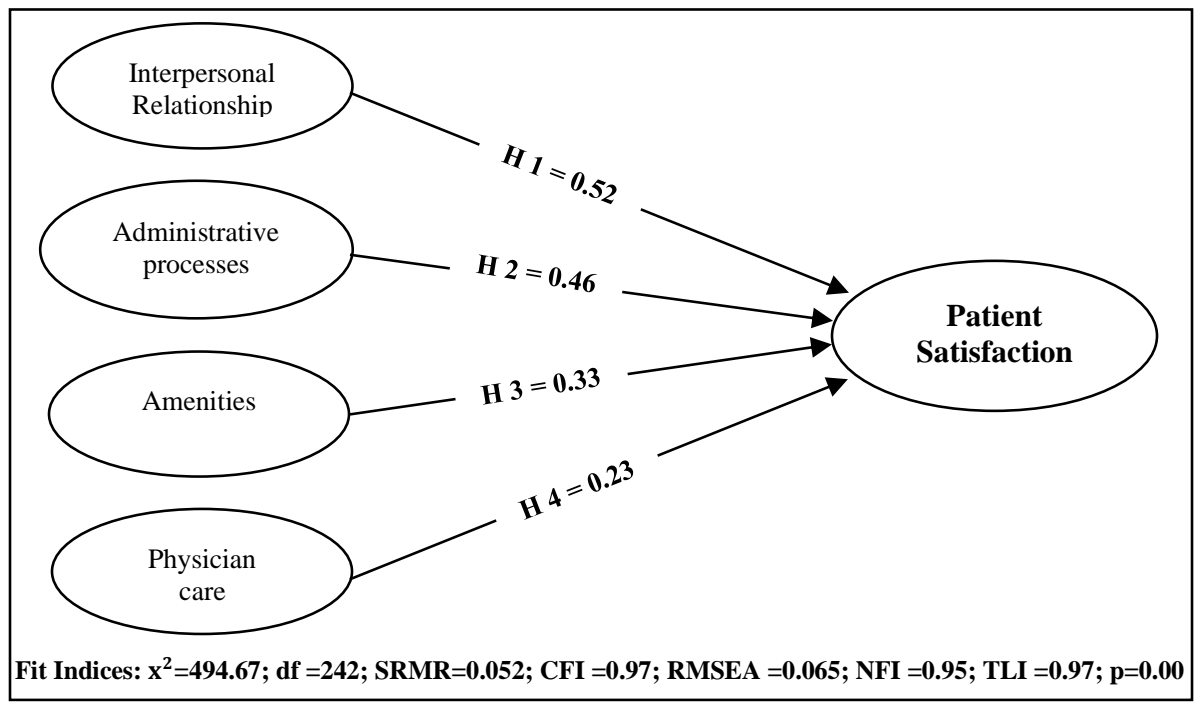

Figure 1 Results of the Estimated Model 
The results of structural equation modeling (SEM) indicated that the four-factor model represented a good fit to the data: chi-square $=494.67$; degrees of freedom $=$ $242 ; \mathrm{SRMR}=0.052 ; \mathrm{p}=0.00 ; \mathrm{CFI}=0.97 ; \mathrm{TLI}=0.97 ; \mathrm{NFI}=0.95 ; \mathrm{RMSEA}=0.065$.

\section{Discussion and Implications}

This study contributes to the literature by exploring the patient satisfaction drivers in the context of public hospital service in Iran, a developing country. To that end, we develop a model to explain the relationship between perceived service quality and patient satisfaction. Our results proved that there is a robust relationship between service quality dimensions and satisfaction for Iranian inpatients. The model encompasses four dimensions: interpersonal relationship, administrative processes, amenities, and physician care. Results of EFA showed that 72.6 percent of the total variation in patient satisfaction was explained by the four-dimension structure, which was higher than the recommended level (Hair et al, 2019). Also, the four-dimensional structure confirmed by construct validity based on confirmatory factor analysis. Therefore, the findings suggested the four primary dimensions as important determinants of the patient satisfaction. Considering the explained variance, "interpersonal relationship" was the most important dimension of service quality from the patients' perspective and have the greatest impact on the satisfaction. This result is in line with the previous studies conducted on service quality and patient satisfaction. Donabedian (1992) argued that patient satisfaction was greatly influenced by the properties of the interpersonal exchange. Choi et al. (2005) suggested that staff concern influence patient satisfaction the most, Badri and Attia (2008) highlighted the humanity side of the health care service, and Zarei et al. (2014) indicated the importance of the interpersonal relationship as an antecedent of patient satisfaction in the context of private hospitals in Iran. In fact, our findings confirm the concept that patients are more satisfied when they perceive care providers and support staff treat them with courtesy, take their problems seriously and respect their patient preferences (Vogus and McClelland, 2016).

"Administrative processes" was the second important dimension influencing the satisfaction according to the results of this study. In line with this finding, Duggirala et al. (2008) indicated that there is a positive and significant relationship among administration procedure and patient satisfaction, and Mohamed and Azizan (2015) proved that administration procedure influence service quality perception and patient satisfaction. Also, Zineldin et al. (2011) argued that "processes" is an element of service quality which is one of determinants of patient satisfaction.

"Hospital amenities" took the next rank based on the explained variance and impact on the satisfaction. Inpatients stay in hospital for an extended time and are likely to be in pain and under great stress, therefore hospital amenities are important to them as clue to perception of service quality (Berry et al., 2006). This dimension has been highlighted in several previous research settings with different label, such as "tangibles" (Choi et al., 2005), "environment quality" (Dagger et al., 2007), "infrastructure" (Duggirala et al., 2008; Zineldin et al., 2011; Mohamed and Azizan, 2015), and "facilities and environment" (Kim et al., 2017)

"Physician care" was the fourth dimension influencing the satisfaction. This finding is consistent with the several previous empirical studies which have proved the impact of physician care on patient satisfaction. Shabbir and Malik (2016) proposed that 
physician care was significantly related with patient satisfaction, and Kim et al (2017) suggested that the performance of physicians is an important factor in patient satisfaction.

\section{Managerial Implications}

Monitoring patient satisfaction is controversial and important issue for managers because it is inconceivable providing good medical care without patient satisfaction. Having satisfied patients are viewed as indispensable indicator of sustainable health care service quality improvement (Cleary and McNeil, 1988; Tam, 2007). Results of this study can help hospital managers to understand significant determinants of patient satisfaction in order to identify the areas of service delivery in need of improvement. This understanding of patient's priorities can prevent from wasting resources.

Our study emphasizes the vital importance of the employees' interaction with patients. This would mean hospital managers must become more aware of the importance of the employees-patient relationship as a critical asset in achieving patient satisfaction. The crucial role of employees is a great opportunity, if they are trained and motivated to provide patient-oriented and compassionate service. However, serving acutely ill people in long hours work shifts with little downtime is exceedingly stressful and interaction with patient is difficult under this working condition (Berry and Bendapudi, 2007). Thus, hospital managers should implement strategies that focus on strengthening employees' communication skills, as well as improving their working conditions in order to reduce burnout among doctors and nurses.

In addition, our findings suggested the importance of optimizing administrative processes in an effort to reduce time of processes. Therefore, hospital managers should continuously restructure conventional administrative processes in order to optimize time and resources.

\section{Limitations and Future Research}

As with any study, this study has several limitations that can be useful for future research in the field. The study sample was selected from available respondents to the research team and the sample size was relatively small. Future studies using systematic random sampling method would improve the generalizability of the findings. As it discussed earlier, satisfaction is an affective reaction resulting from patients' evaluation regarding the quality of care. Thus, perceived service quality as a cognitive construct and satisfaction as an affective construct depend on individuals' thoughts, beliefs and emotions. Consequently, to explore specific dimensions and subdimensions of service quality that affect satisfaction, using qualitative methods like interviews and group discussions along with the quantitative methods may better reflect the patients' perspective. As argued in this study, interpersonal relationship between employees and patients is the most crucial factor affecting patient satisfaction. Future research should investigate strategies which can improve the quality of employees' interaction with patient in the context of hospitals.

\section{References}

1. Aagja, J.P. and Garg, R. (2010), "Measuring perceived service quality for public hospitals (PubHosQual) in the Indian context", International Journal of Pharmaceutical and Healthcare Marketing, Vol.4 No.1, pp. 60-83. 
2. Amin, M. and Nasharuddin, S.Z. (2013), "Hospital service quality and its effects on patient satisfaction and behavioural intention", Clinical Governance: An International Journal, Vol.18 No.3, pp. 238-254.

3. Andaleeb, S.S. (2001), "Service quality perceptions and patient satisfaction: a study of hospitals in a developing country", Social science \& medicine, Vol.52, No.9, pp.1359-1370.

4. Babakus, E. and Boller, G.W. (1992), "An empirical assessment of the SERVQUAL scale", Journal of Business research, Vol.24 No. 3, pp.253-268.

5. Badri, M.A., Attia, S.T. and Ustadi, A.M. (2008), "Testing not-so-obvious models of healthcare quality", International journal of health care quality assurance, Vol. 21 No. 2, pp. 159-174.

6. Batbaatar, E., Dorjdagva, J., Luvsannyam, A., Savino, M.M. and Amenta, p. (2017), "Determinants of patient satisfaction: a systematic review", Perspectives in Public Health, Vol. 137 No. 2, pp. 89-101.

7. Bendall-Lyon, D. and Powers, T.L. (2004), "The impact of structure and process attributes on satisfaction and behavioral intentions", Journal of Services Marketing, Vol. 18 No. 2, pp. 114-121.

8. Berry L.L. and Bendapudi, N. (2007), "Health Care: A Fertile Field for Service Research”, Journal of Service Research, Vol. 10 No. 2, pp. 111-122.

9. Berry, L.L., Wall, E.A., and Carbone, L.P. (2006), "Service clues and customer assessment of the service experience: Lessons from marketing" Academy of Management Perspectives, Vol.20 No.2, pp. 43-57.

10. Brady, M.K. and Cronin, J.J. (2001), "Some new thoughts on conceptualizing perceived services quality: a hierarchical approach", Journal of Marketing, Vol. 65 No. 3, pp. 34-49.

11. Brady, M.K. and Robertson, C.J. (2001), "Searching for a consensus on the antecedent role of service quality and satisfaction: an exploratory cross-sectional study", Journal of Business Research, Vol. 51 No. 1, pp. 53-60.

12. Butt, M.M. and De Run, E.C. (2010), "Private healthcare quality: applying a SERVQUAL model", International journal of health care quality assurance, Vol. 23 No. 7, pp. 658-673.

13. Carman, J.M. (2000), "Patient perceptions of service quality: combining the dimensions", Journal of Services Marketing, Vol. 14 No. 4, pp. 337-52.

14. Chahal, H. and Kumari, N. (2010), "Development of multidimensional scale for healthcare service quality in Indian context", Journal of Indian Business Research, Vol. 2 No. 4, pp. 230-255.

15. Choi, K.S., Lee, H., Kim, C. and Lee, S. (2005), "The service quality dimensions and patient satisfaction relationships in South Korea: comparisons across gender, age and types of service", Journal of Services Marketing, Vol. 19 No. 3, pp. 140149.

16. Cleary, P.D. and McNeil, B.J. (1988), "Patient satisfaction as an indicator of quality care", Inquiry, Vol. 25 No. 1, pp. 25-36.

17. Clemes, M.D., Ozanne, L.K. and Laurensen, W.L. (2001), "Patients' Perceptions of Service Quality Dimensions: An Empirical Examination of Health Care in New Zealand", Health Marketing Quarterly, Vol.19 No.1, pp. 3-22.

18. Cronin Jr, J.J. and Taylor S.A. (1992), "Measuring service quality: a reexamination and extension”, Journal of marketing, Vol.56 No. 3, pp. 55-68. 
19. Dabholkar, P.A., Shepherd, C.D. and Thorpe, D.I. (2000), "A comprehensive framework for service quality: an investigation of critical conceptual and measurement issues through a longitudinal study", Journal of retailing, Vol. 76 No. 2, pp. 139-173.

20. Dagger, T.S., Sweeney, J.C. and Johnson, L.W. (2007), “A hierarchical model of health service quality: scale development and investigation of an integrated model", Journal of Service Research, Vol. 10 No. 2, pp. 123-142.

21. De Ruyter, K., Bloemer, J. and Peeters, P. (1997), "Merging service quality and service satisfaction. An empirical test of an integrative model", Journal of economic psychology, Vol. 18 No. 4, pp. 387-406.

22. Donabedian, A. (1992), "The Lichfield Lecture. Quality assurance in health care: consumers' role", Quality in Health care, Vol. 1 No. 4, pp. 247-251.

23. Doran, D. and Smith, P. (2004), "Measuring service quality provision within an eating disorders context", International Journal of Health Care Quality Assurance, Vol. 17 No. 7, pp. 377-388.

24. Duggirala, M., Rajendran, C. and Anantharaman, R.N. (2008), "Patient-perceived dimensions of total quality service in healthcare", Benchmarking: An International Journal, Vol. 15 No. 5, pp. 560-583.

25. Elleuch, A. (2008), "Patient satisfaction in Japan", International journal of health care quality assurance, Vol. 21 No. 7, pp. 692-705.

26. Gill, L. and White, L. (2009), "A critical review of patient satisfaction", Leadership in Health Services, Vol. 22 No. 1, pp. 8-19.

27. Gronroos, C. (1984), "A service quality model and its marketing implications", European Journal of Marketing, Vol. 18 No. 4, pp. 36-44.

28. Hair, J.F., Black, W.C., Babin, B.J. and Anderson, R.E. (2019), "Multivariate Data Analysis", 8th edition, Cengage, U.K.

29. Hekman, D.R., Aquino, K., Owens, B.P., Mitchell, T.R., Schilpzand, P. and Leavit, K. (2010), “An examination of whether and how racial and gender biases influence customer satisfaction”, Academy of Management Journal, Vol. 53 No. 2, pp. 238-264.

30. Herstein, R. and Gamliel, E. (2006), "The role of private branding in improving service quality", Managing Service Quality: An International Journal, Vol. 16 No. 3, pp. 306-319.

31. Johnson, D.M. and Russell, R.S., (2015), "SEM of service quality to predict overall patient satisfaction in medical clinics: A case study", Quality Management Journal, Vol. 22 No. 4, pp. 18-36.

32. Karami, M, Maleki, M.M. and Dubinsky, A.J. (2016), "Cultural values and consumers' expectations and perceptions of service encounter quality", International Journal of Pharmaceutical and Healthcare Marketing, Vol. 10 No.1, pp. 2-26.

33. Karassavidou, E., Glaveli, N. and Papadopoulos, C.T. (2009), "Quality in NHS hospitals: no one knows better than patients", Measuring Business Excellence, Vol. 13 No. 1, pp. 34-46.

34. Kim, C.E., Shin J.S., Lee J., Lee Y.J., Kim, M., Choi, A., Park, K.B., Lee, H.G. and Ha, I.H. (2017), "Quality of medical service, patient satisfaction and loyalty with a focus on interpersonal-based medical service encounters and treatment effectiveness: a cross-sectional multicenter study of complementary and 
alternative medicine (CAM) hospitals", BMC Complementary and Alternative Medicine, Vol. 17 No. 174.

35. Lee, H., Lee, Y. and Yoo, D. (2000), "The determinants of perceived service quality and its relationship with satisfaction", Journal of Services Marketing, Vol. 14 No. 3, pp. 217-231.

36. Linder-Pelz, S. (1982), "Social psychological determinants of patient satisfaction: A test of five hypotheses", Social Science \& Medicine, Vol.16 No. 5, pp. 583589.

37. Meesala, A. and Paul, J. (2018), "Service quality, consumer satisfaction and loyalty in hospitals: Thinking for the future", Journal of Retailing and Consumer Services, Vol. 40, pp. 261-269.

38. Mehrdad, R. (2009), "Health system in Iran", JMAJ, Vol. 52 No.1, pp.69-73.

39. Mohamed, B. and Azizan, N.A. (2015), "Perceived service quality's effect on patient satisfaction and behavioural compliance", International Journal of Health Care Quality Assurance, Vol. 28 No. 3, pp. 300-314.

40. Murfin, D.E., Schlegelmilch, B.B. and Diamantopoulos, A. (1995), "Perceived service quality and medical outcome: an interdisciplinary review and suggestions for future research", Journal of Marketing Management, Vol. 11 No. 1-3, pp. 97117.

41. Naidu, A. (2009), "Factors affecting patient satisfaction and healthcare quality", International Journal of Health Care Quality Assurance, Vol. 22 No. 4, pp. 366381.

42. Nembhard, I.M., Alexander, J.A., Hoff, T., and Ramanujam, R. (2009), "Why does health care continue to lag? Insights from management research", Academy of Management Perspectives, Vol.23 No.1, pp. 24-42.

43. Oliver, R. L. (1993), "A conceptual model of service quality and service satisfaction: compatible goals, different concepts", Advances in Service Marketing and Management, Vol. 2, pp. 65-85.

44. Oliver, R.L. (1980), "A cognitive model of the antecedents and consequences of satisfaction decision", Journal of Marketing Research, Vol. 17 No. 4, pp. 460-9.

45. Parasuraman, A., Zeithaml, V. and Berry, L. (1985), "A conceptual model of service quality and its implications for future research", Journal of Marketing, Vol. 49 No. 4, pp. 41-50.

46. Parasuraman, A., Zeithaml, V.A. and Berry, L.L. (1988), "SERVQUAL: a multiple-item scale for measuring consumer perceptions of service quality", Journal of Retailing, Vol. 64 No. 1, pp. 12-40.

47. Ramsaran-Fowdar, R.R. (2008), "The relative importance of service dimensions in a healthcare setting", International Journal of Health Care Quality Assurance, Vol. 21 No. 1, pp. 104-124.

48. Ravangard, R., Farhadi, P., Shokrpour, N., Niyas, M. and Sajjadnia, Z. (2017), "Assessing the Quality of Services Provided in the Teaching Hospitals A Case Study of Iran", The Health Care Manager, Vol. 36, No. 1, pp. 69-77.

49. Reidenbach, R.E. and Sandifer-Smallwood, B. (1990), "Exploring perceptions of hospital operations by a modified SERVQUAL approach", Journal of Health Care Marketing, Vol. 10 No. 4, pp. 47-55.

50. Ryu, K., Han, H. and Kim, T.H. (2008), "The relationships among overall quickcasual restaurant image, perceived value, customer satisfaction, and behavioral 
intentions", International Journal of Hospitality Management, Vol. 27 No. 3, pp. 459-469.

51. Senić, V. and Marinković, V. (2013), "Patient care, satisfaction and service quality in health care", International Journal of Consumer Studies, Vol. 37 No. 3, pp. 312-319.

52. Shabbir, A., Malik, S.A. and Malik, S.A. (2016), "Measuring patients' healthcare service quality perceptions, satisfaction, and loyalty in public and private sector hospitals in Pakistan", International Journal of Quality \& Reliability Management, Vol. 33 No. 5, pp. 538-557.

53. Spreng, R.A. and MacKoy, R.D. (1996), "An empirical examination of a model of perceived service quality and satisfaction", Journal of Retailing, Vol. 72 No. 2, pp. 201-14.

54. Swain, S. and Kar, N.C. (2018), "Hospital service quality as antecedent of patient satisfaction - a conceptual framework", International Journal of Pharmaceutical and Healthcare Marketing, Vol. 12 No. 3, pp. 251-269.

55. Tam, J.L.M. (2007), "Linking quality improvement with patient satisfaction: a study of a health service centre", Marketing Intelligence \& Planning, Vol. 25 No. 7, pp. 732-745.

56. Tucker, J.L. (2002), "The moderators of patient satisfaction", Journal of Management in Medicine, Vol. 16 No. 1, pp. 48-66.

57. Vogus, T.J. and McClelland, L.E. (2016), "When the customer is the patient: Lessons from healthcare research on patient satisfaction and service quality ratings", Human Resource Management Review, Vol. 26 No. 1, pp. 37-49.

58. Westbrook, R.A. and Oliver, R.L. (1991), "The dimensionality of consumption emotion patterns and consumer satisfaction", Journal of consumer research, Vol. 18 No. 1, pp. 84-91.

59. Williams, B. (1994), "Patient satisfaction: a valid concept?", Social Science and Medicine, Vol. 38 No. 4, pp. 509-516.

60. Wisniewski, M. and Wisniewski, H. (2005), "Measuring service quality in a hospital colposcopy clinic", International Journal of Health Care Quality Assurance, Vol. 18 No. 3, pp. 217-228.

61. Woodside, A.G., Frey, L.L. and Daly, R.T. (1989), "Linking service quality, customer satisfaction, and behavioral intention", Journal of Health Care Marketing, Vol. 9, December, pp. 5-17.

62. Zarei, E. (2015), "Service quality of hospital outpatient departments: patients' perspective", International Journal of Health Care Quality Assurance, Vol. 28 No. 8, pp. 778-790.

63. Zarei, E., Arab, M., Tabatabaei, S.M.G., Rashidian, A, Forushani, A.R. and Khabiri, R. (2014), “Understanding patients' behavioral intentions Evidence from Iran's private hospitals industry", Journal of Health Organization and Management, Vol. 28 No. 6, pp. 795-810.

64. Zeithaml, V.A. (1988), "Consumer perceptions of price, quality, and value: a means-end model and synthesis of evidence", Journal of marketing, Vol. 52 No. 3, pp. 2-22.

65. Ziapour, A., Khatony, A., Jafari, F. and Kianpour, N. (2016), "Patient satisfaction with medical services provided by a hospital in Kermanshah- Iran", Acta Med Mediterranea, Vol. 32, pp. 959-65. 
66. Zineldin, M. (2006), "The quality of health care and patient satisfaction: An exploratory investigation of the 5Qs model at some Egyptian and Jordanian medical clinics", International Journal of Health Care Quality Assurance, Vol. 19 No. 1, pp. 60-92.

67. Zineldin, M., Camgöz-Akdağ, H. and Vasicheva, V. (2011), "Measuring, evaluating and improving hospital quality parameters/dimensions - an integrated healthcare quality approach", International Journal of Health Care Quality Assurance, Vol. 24 No. 8, pp. 654-662.

\section{About Our Authors}

Rassoul Noorossana is a professor of Applied Statistics in the Industrial Engineering Department at Iran University of Science and Technology. He received his PhD in Statistics from the University of Louisiana at Lafayette in 1990. His primary research interests include data analytics and statistical process monitoring and control. $\mathrm{He}$ is a senior member of the American Society for Quality and Iranian Institute of Industrial Engineering.

Adel Talaei Delshad holds an EMBA from Iran University of Science and Technology and a bachelor's degree in Industrial Engineering from Azad University, South Tehran Branch. His research interests include service marketing, marketing strategy, and marketing analytics.

Mike Nayebpour is faculty of business and management at Marilyn Davies College of Business of the University of Houston-Downtown. He is a business/management consultant and educator with over 30 years of experience in the industry and higher education. He has extensive experience as an industry consultant in areas of quality management, operations management, statistical process control, data analysis, forecasting, financial modeling, optimization techniques, sampling methodology, and project management. 